\title{
Structural Optimization of Network Arch Bridges with Hollow Tubular Arches and Chords
}

\author{
Alessio Pipinato ${ }^{1}$ \\ ${ }^{1}$ AP\&P S.r.1., Structural Engineering Dpt., Padova, Italy \\ Correspondence: Alessio Pipinato, AP\&P S.r.l., Structural Engineering Dpt, Padova, Italy. Tel: 39-042-549-0406. \\ E-mail: info@pipinatoandpartners.it
}

Received: December 30, 2017

Accepted: January 6, 2018

Online Published: January 11, 2018

doi:10.5539/mas.v12n2p36

URL: https://doi.org/10.5539/mas.v12n2p36

The research is financed by AP\&P S.r.l., Structural Engineering Institute.

\begin{abstract}
In the framework of bridge engineering, cable structure represent a key argument. The development of innovative bridge solutions are needed in order to keep time and costs at a reasonable level, maintaining at the same time an high level of structural safety and functionality. The network arch bridge solution completely respond to these requirements, and in addition could be designed as a very pleasant and formally elegant structure, because of its slenderness and lightness. In this paper, an introduction on the network arch solution is presented, together with structural analysis and data of relevant structures realized. Furthermore, an optimization of specific types of road and railway bridges is presented in the particular case of hollow sections, considering three alternative of cable disposition.
\end{abstract}

Keywords: cable structure, bridges, stress analysis, fatigue, steel structures

\section{Introduction}

\subsection{Introduce the Problem}

Bridge engineers should deserve a particular attention for network arches. These structures in fact are highly performant for medium span bridge solutions, and almost ever preferably if compared to traditional arch, both in the road and the railway case. Reference works on the matter includes Tveit (1966) Shanack (2003), Tveit (2010), Tveit and Pipinato (2011), describing the structural performance of net-arches compared to traditional solutions. However similar works exists on the matter (e.g. Teich 2012; Brunn and Schanack 2003, Dimopoulos and Gantes 2007), the paper innovates the state of knowledge by the use of a new software able to: (a) compare roadway and railway solutions according to EN loads, and (b) exploring different span lengths.

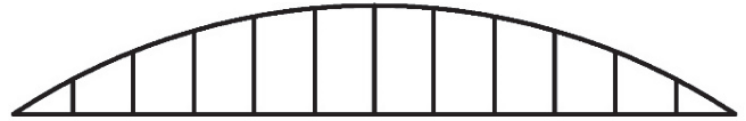

Vertical hangers

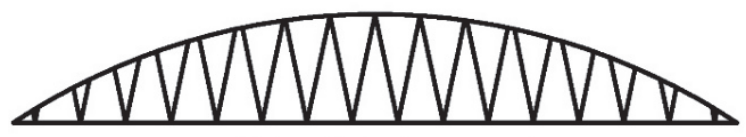

Nielsen-type hanger net

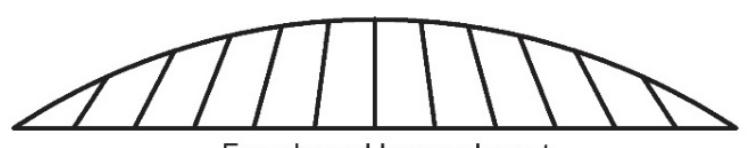

Fan-shaped hanger layout

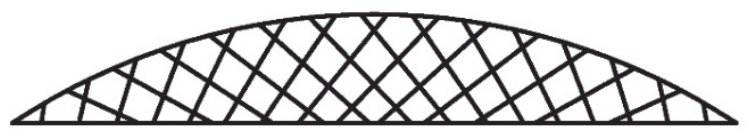

Network arch with radial hanger distribution

Figure 1. Hanger layout in tied arch bridges

The idea comes from the past, as first drawing of similar solution appeared in 1482, in a manuscript of Leonardo Da Vinci, designing in the "Codex Atlanticus" a truss arch with inclined hangers, probably wooden made. In 1796, American engineer Robert Fulton published a design of a bridge with a type of truss beam that he called "bowstring." His idea is based on an arch where concentrated loads are uniformly distributed by a truss and the 
lateral abutments are replaced by a tie between the arch ends (Shanak, 2015). Similar archetypes of the network arch could be found among some parental bridges: the Whipple bridges (Griggs, 2002), the lenticular bridge, or Pauli girder (a truss with a curved top and a curved bottom chord); the Lohse bridge (1872, Hermann Lohse lenticular girder with only vertical members between the chords); the Nielsen bridge (1925, Octavius F. Nielsen inclined hangers intersecting once at most). Finally, in 1955, the norwegian engineer and profesor Per Tveit started working on Nielsen bridges using new analysis methods that allowed him to calculate and develop tied arch bridges with multiple intersecting hangers, which he called "network arch bridges" (Tveit, 1966) (Figure 1). More publications on the matter exists, however, a systematic overview on the matter, including structural details, analysis, and optimization is not available. Recent investigation of the author includes a multi-span network arch project case for large span (Pipinato, 2016). As a first definition, network arches could be defined as a simply supported beam, in which the arch is the compression zone, the tie is the tension zone, and the inclined hangers are the web. Most of the shear force is taken by the vertical component of the compressive force in the arch. Some of the variation in the shear force is taken by the hangers. Throughout this structural model, bending is reduced at minimum in all elements. This bridge solution is generally suitable for medium span, as mentioned before, and optimal between 60 and $200 \mathrm{~m}$ for road bridges, and up to $150 \mathrm{~m}$ for railway bridges. The diagram in Figure 2 has been presented to find network arch bridge alternatives, giving an estimate of the materials needed for double track road bridges spanning in the field-span of network arches (Tveit, 2014). Similarly, the second diagram in Figure 3 represents an estimate for two lane railway bridges up to $150 \mathrm{~m}$ span (Shanack 2003).

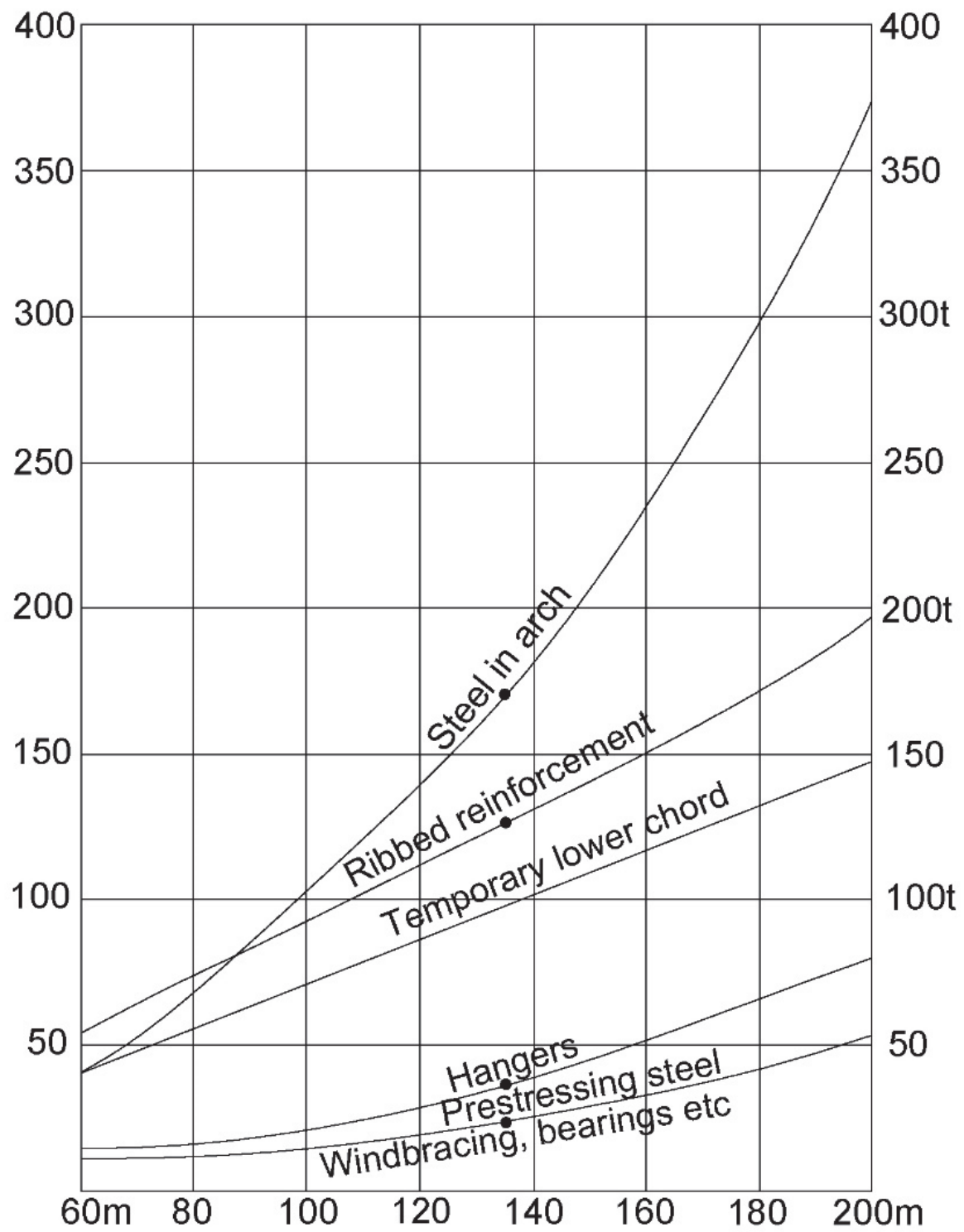

Figure 2. Steel needed for various two-lane road bridges between $60 \mathrm{~m}$ and $200 \mathrm{~m}$ span lenght (Tveit, 2011). 
Table 1. European and American built network arches (in order of L/f ratio).

\begin{tabular}{|c|c|c|c|c|c|c|c|}
\hline Brudge name & Nation & $\begin{array}{l}\text { Span } \\
{[\mathrm{m}]}\end{array}$ & $\begin{array}{l}\text { Arch } \\
{[\mathrm{m}]}\end{array}$ & rise & $\mathrm{L} / \mathrm{f}$ & $\mathrm{F} / \mathrm{L}$ & Reference \\
\hline Salzbergen & Germany & 56 & 12,85 & & 4,36 & 0,23 & Geißler et al. (2008) \\
\hline Providence Rohde Island & USA & 122 & 24,4 & & 5 & 0,20 & Tveit and Pipinato (2011) \\
\hline Blennerhassett & USA & 267,7 & 53,3 & & 5,03 & 0,20 & Tveit and Pipinato (2011) \\
\hline Po Brondolo road bridge & Italy & 70 & 13,7 & & 5,1 & 0,20 & Pipinato (2016) \\
\hline Bolstadstraumen & Norway & 85 & 15 & & 5,6 & 0,18 & Tveit and Pipinato (2011) \\
\hline Fehmarnsundbrücke & Germany & 248 & 43 & & 5,77 & 0,17 & Stein and Wild (1965) \\
\hline Brandangersund & Norway & 220 & 37,4 & & 5,88 & 0,17 & Tveit and Pipinato (2011) \\
\hline Mainbrücke Marktheidenfeld & Germany & 135 & 22,5 & & 6 & 0,17 & $\begin{array}{l}\text { Müller-Donges, } \\
\text { (2003) }\end{array}$ \\
\hline A38, Leipzi & Germar & 87,9 & 14 & & 6,28 & 0,16 & Geißler et al. (2008) \\
\hline NATO-Rampe & Germany & 150 & 23,75 & & 6,32 & 0,16 & Schömig (2000) \\
\hline $\begin{array}{l}\text { Oder-Havel-Kanal- } \\
\text { Hennigsdorf }\end{array}$ & Germany & 97,4 & 15 & & 6,49 & 0,15 & Geißler et al. (2008) \\
\hline B6 Halle & Germany & 79 & 11,95 & & 6,61 & 0,15 & Geißler et al. (2008) \\
\hline Steinkjerbrücke & Norway & 79,75 & 12 & & 6,65 & 0,15 & Tveit and Pipinato (2011) \\
\hline Florabrücke & Germany & 132,6 & 19,85 & & 6,68 & 0,15 & Geißler et al. (2008) \\
\hline Bechyne-Bridge & $\begin{array}{l}\text { Czech } \\
\text { Republic }\end{array}$ & 41 & 6,05 & & 6,78 & 0,15 & Tveit and Pipinato (2011) \\
\hline Dziwna-Brücke Wolin & Polony & 165 & 24 & & 6,88 & 0,15 & Zoltowski,K. (2005) \\
\hline Carbon-River Brücke & Peru & 120 & 16,2 & & 7,41 & 0,14 & Tveit and Pipinato (2011) \\
\hline
\end{tabular}

a)
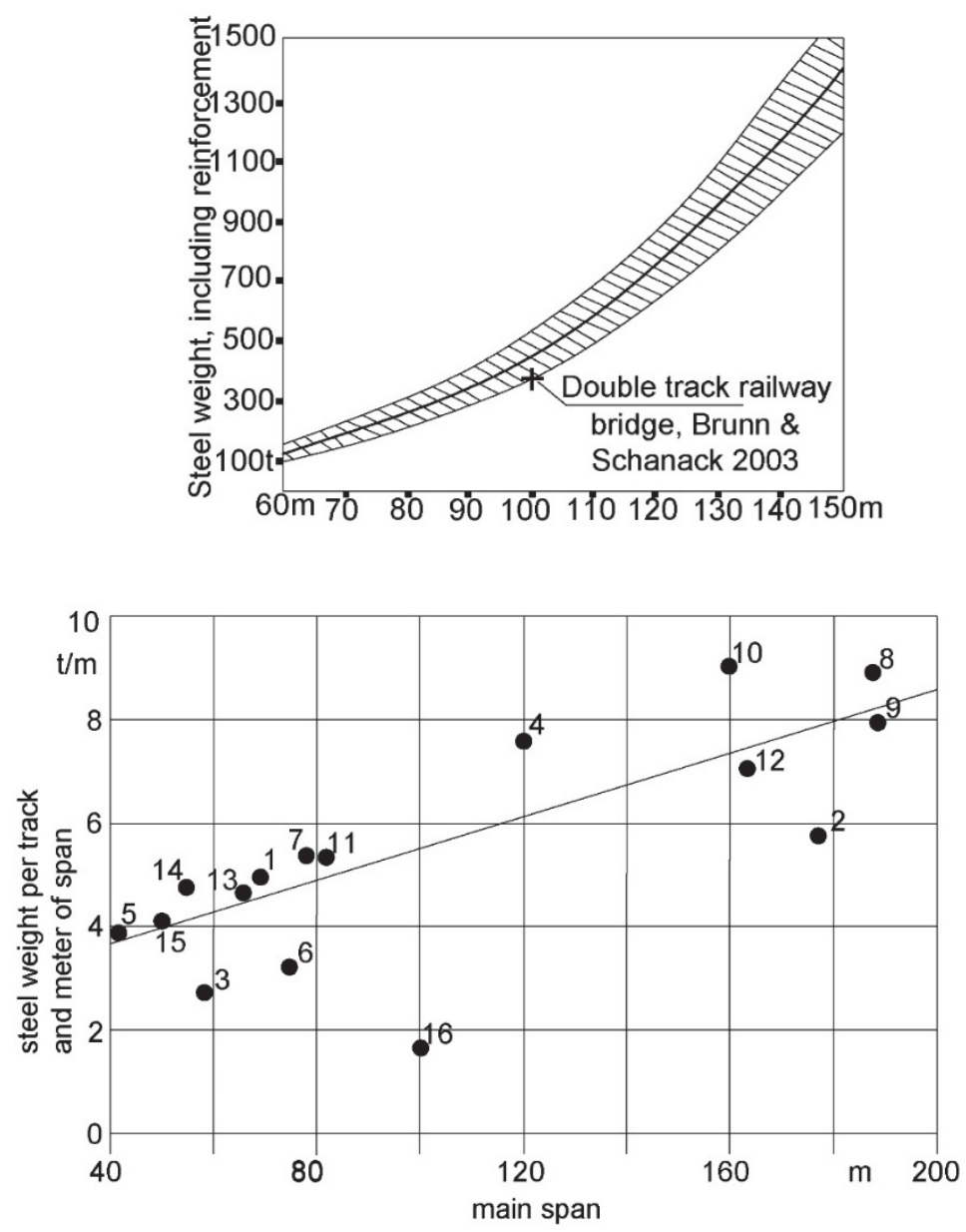

b)

Figure 3. a) Steel weight in two-track railway arches with concrete deck bridges between $60 \mathrm{~m}$ and $150 \mathrm{~m}$ span lenght (Shanack, 2003); b) Steel weight of railway bridges with ballast 
In the first stage of the network arch study and design, some of the hangers where not in tension for particular loading condition (asymmetric). To avoid this and to optimize the model, the geometry is changed, by the introduction of new hangers, and in this way all the hangers were in tension, consequently structural steel and shape was optimal, the arch doesn't have instability problems, and finally the bending stress on the deck is lower. While arches are usually made up of structural steel, the deck could be realized with a post-tensioned deck, or with a concrete-steel mixed section, or with a steel deck, or finally a combination thereof. One of the most performing solution is the post-tensioned deck, even if the choice of the effective structure should be chosen according to the design specifications and requirements. The hangers geometry and the hangers disposition is strictly related to the deck type adopted: if an all-concrete deck solution is adopted, the hangers design could be varied along the deck without any fixed position that is imposed from the geometry of the transverse beam in the steel solution. Some suggestions are given in literature (Tveit 1966; Tveit 2010; Tveit and Pipinato 2011) in order to design the final shape of the structure. In this particular case, transverse are present as a result of the structural optimization performed. Hangers geometry/inclination is given by non-dimensional numerical values related to Live Load vs. Dead Load ratio and Live Load vs. bridge span. In order to understand this, a traditional arch with inclined hangers and subjected to a non-symmetric loading could be considered: hangers are alternatively in tension and compression (Figure 4). To optimize this model, in order to have all hangers in tension and a lower effect of bending on the chord, another series of hangers should be added, as described in the following figure (Figure 5). Adding a new series of hangers, the beneficial aspects includes a minor arch buckling value, and minor bending effects on the chord and on the arch, developing a so called network arch (Figure 6).

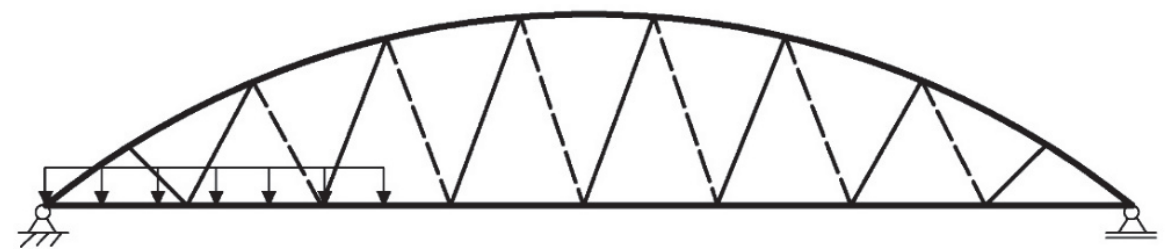

Figure 4. Traditional arch bridge with inclined strands with an asymmetric loading condition.

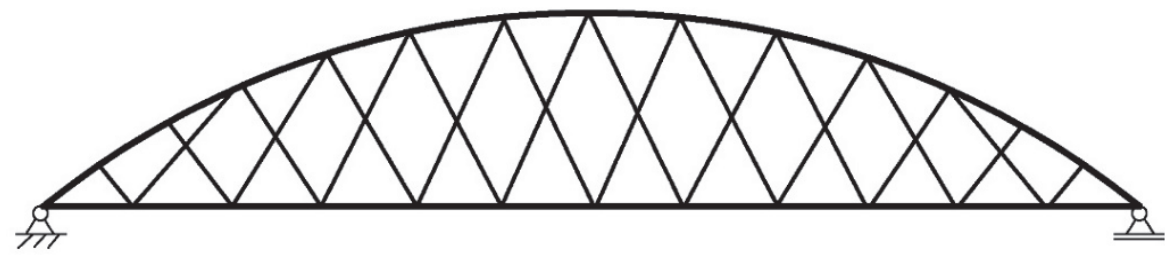

Figure 5. Arch bridge with a double net of inclined strands.

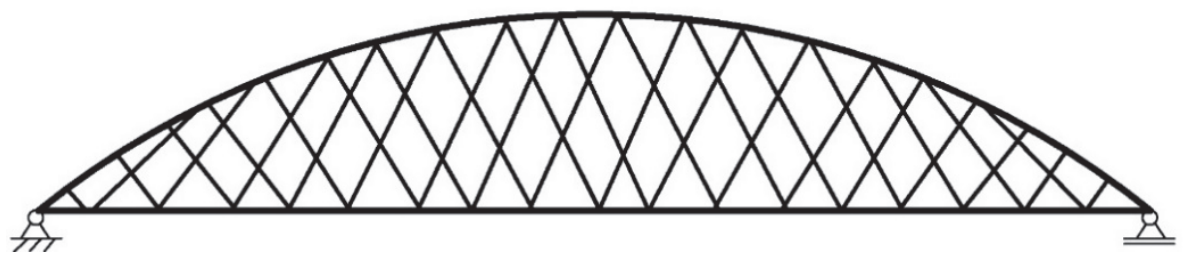

Figure 6. Network arch bridge.

\section{Structural Components}

\subsection{Arches Optimization}

The shape of the arch is chosen after a parametric analysis, finalized to minimize the steel amount needed to carry the live and dead load of the particular solution investigated. Circular arch shape are often found to be the optimal solution for the design of network arches (Pipinato 2016; Tveit and Pipinato 2011). The arch rise is normally $0.15-0.20$ times the span, according to the coded loading scheme adopted (Table 1 ). The box section is 
usually represented by a squared or a circular commercial section for $100 \mathrm{~m}$ and more span; for shorter span, universal columns or American wide flange beams, with profiles bent to the right curvature would be a correct solution (Tveit 2010); this alternative enable for attaching hangers and wind bracing connections in a easier way. If a parabola shape is chosen, according to the parametric analysis mentioned before, the arch shape should be near parabola of 2nd degree (Tveit 2010). When the arch is steel made, a constant curvature should be preferred. The constant curvature - if compared to the parabolic solution - gives in the middle of the arch more even force and wind portals shorter, resulting at the same time easier to be built. Other arch curvatures resulted to be in a moderate level of savings. If near the ends of the arches a smaller radius of curvature is used, the wind portal will be shorter and the force in the middle half of the arch will be smaller. It would also lead to the maximum bending stress in the chords (Brunn \& Schanack 2001). With elliptic arches a similar effect could be reproduced (Teich 2012). If in the tie the last members are built shorter, the consequent bending and rotation at the end of the bridge would be reduced and the tension in the shortest hanger would be very similar to the tension in the longer one (Tveit 2008). The absence of transversal beams in the tie, suggests to maintain constant the distance between the nodal points in the arch. At the end of the span the arch members could be 1.5-1.7 times longer than the other member of the arch. The concrete filled steel tube solution (CFST) could be evaluated for longer span, and are found to be economically convenient in the nearest of $200 \mathrm{~m}$ span. The possible form of buckling in the plane of a network arch is represented in Figure 7. The buckling argument have been threated e.g. in Schanack (2009): with reference to the notation reported in Figure 8, it can be demonstrated that sufficiently accurate results are found if it is assumed that the tie remains straight.

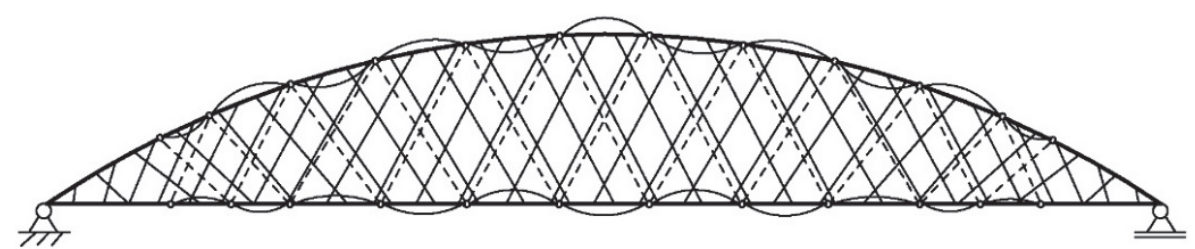

Figure 7. Possible form of buckling in the plane of a network arch.

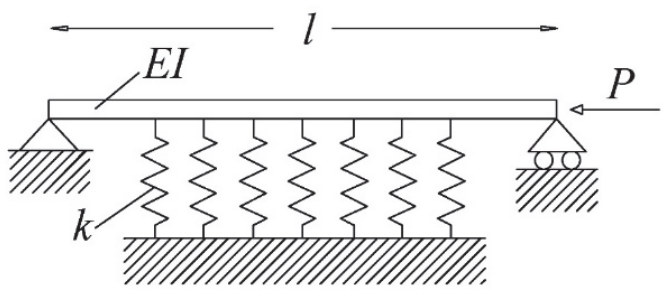

Figure 8. Strait compressive member with elastic support.

In this case, the arch buckles like a column supported by flexible springs, and the problem becomes much simpler, implying:

$$
\mathrm{P}_{\mathrm{cr}}=\min \left(\left(\frac{\mathrm{n} \cdot \pi}{\ell}\right)^{2} \cdot \mathrm{EI}+\left(\frac{\ell}{\mathrm{n} \cdot \pi}\right)^{2} \cdot \mathrm{k}\right)
$$

Where

$\mathrm{n}=$ number of waves

Pcr $=$ buckling load

$\mathrm{EI}=$ stiffness of member

$1=$ Length of member

$\mathrm{k}=$ stiffness of support

For the maximum load on the whole bridge it has been shown (Schanack 2008) that the buckling load is approximatively: 


$$
\mathrm{N}_{\mathrm{cr}}=\min \left(\left[\left(\frac{\mathrm{n} \cdot \pi}{\alpha_{0}}\right)^{2}-1\right] \frac{\mathrm{EI}}{\mathrm{R}^{2}}+\frac{\frac{\mathrm{EA} \cdot \mathrm{n}_{\mathrm{p}} \cdot \mathrm{R}}{\mathrm{f} \cdot 2 \cdot \alpha_{0}} \sin ^{3} \alpha}{\left(\frac{\mathrm{n} \cdot \pi}{\alpha_{0}}\right)^{2}-1}\right)
$$

where

$$
\begin{gathered}
R=\frac{\mathrm{f}^{2}+\frac{\mathrm{s}^{2}}{4}}{2 \cdot f} \\
\alpha_{0}=\arcsin \left(\frac{\mathrm{s}}{2 \cdot \mathrm{R}}\right)
\end{gathered}
$$

$\mathrm{f}=$ Rise of arch

$\mathrm{EA}_{\mathrm{p}}=$ Stiffness of a hanger

$\mathrm{EI}_{\mathrm{y}}=$ Stiffness of arch

$\mathrm{s}=$ Span

$\alpha=$ Angle between arch and hangers

$\mathrm{n}=$ Number of waves

$\mathrm{n}_{\mathrm{p}}=$ number of hangers per arch

\subsection{Lower Chords Optimization}

Minimizing bending in chords is the mainframe in the choice of chord type: the solution to this problem could be reached considering the four sources of bending in the network arches. Bending due to concentrated load and abrupt changes in load intensity (a), bending due to relaxation of hangers (b), bending due to distance between nodal points (c), and secondary bending (d):

a) due to concentrated load, as illustrated in figure 9a, bending arises from internal local shear forces originating from the application of the external actions; similarly could be affirmed for abrupt changes, which implies internal shear variations; if a geometry including three set of hangers is adopted (figure 9b) bending is reduced, as the distance that the shear force have to travel in order to make all trusses deflect equally is shortened (Tveit 2008); further deeps on arches with three or four set of hangers are needed, however basing on first estimates on case studies developed by the author, this solution appear to be more costly and not so technologically affordable;

b) relaxation of hangers in net-arch bridges complicates design, as the discontinuous system implies new equations for calculating forces and deflections for each combination of relaxed hangers; the easier solution to avoid relaxation consists in the introduction of smaller angles for hangers in the lower chords, however this implies an increase in bending for the aforementioned concentrated load problem; a straightforward solution consists in the dimensioning of the chords with full loads on the entire span, calculating parametrically the hangers slope optimal solution (inclination, number and geometry) (Tveit and Pipinato 2011);

c) bending due to distance between nodal points could be reduced introducing more hangers; however, a crowded arch is then not suitable for an easy and economical construction, so also this structural choice should be calibrated with parametrical analysis;

d) the global deflection of the whole span induces a predominant positive bending, which originates secondary moments in the chord; this is controlled by the cross section of the chords, from cambering the tie (approximatively of the 1/1000 of the span), and from the optimization of the hanger geometry; moreover, if the deck is built as a composite section, creep and shrinkage will contribute to counteract this type of secondary bending. To ensure the maximum control of secondary moments, a calculation based on the deflected state will give the exact values of bending moments, which resulted to be always very small. 

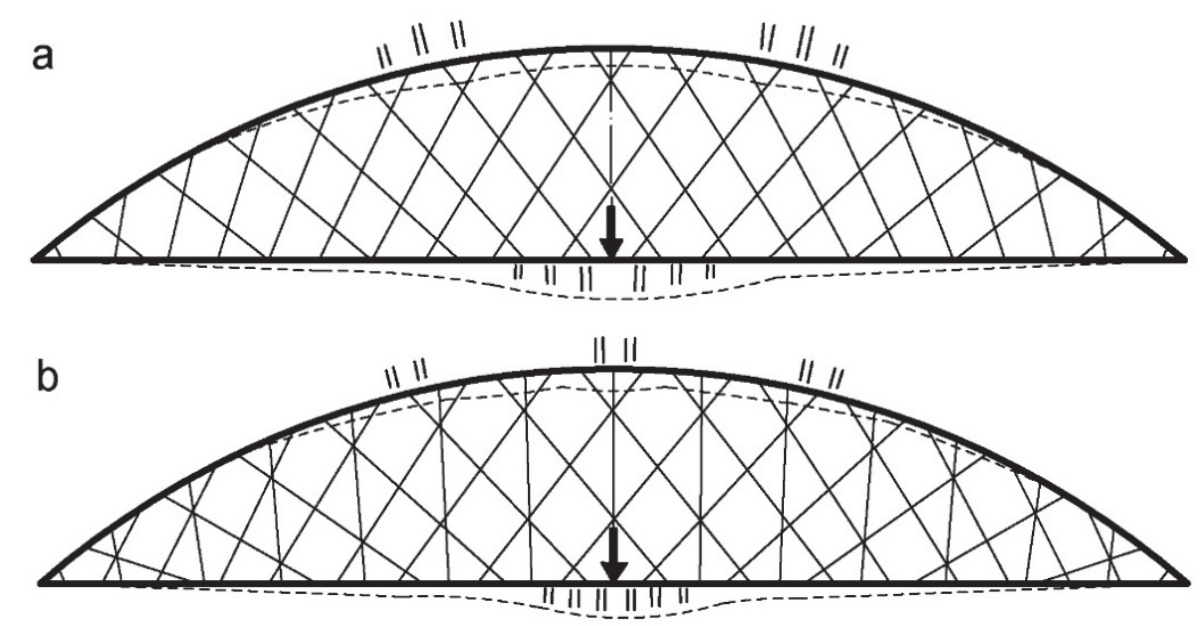

Figure 9. Deflection and shear forces due to concentrated load in network arches with two(a) and three sets of hangers (b)

\section{Hangers Type, Configuration and Optimization}

\subsection{Type}

The hangers type are made of cables (Figure 10). Where the hangers bridges cross each other, one of the hangers is normally covered by a split open plastic tube, in order to avoid local damages due to external actions.

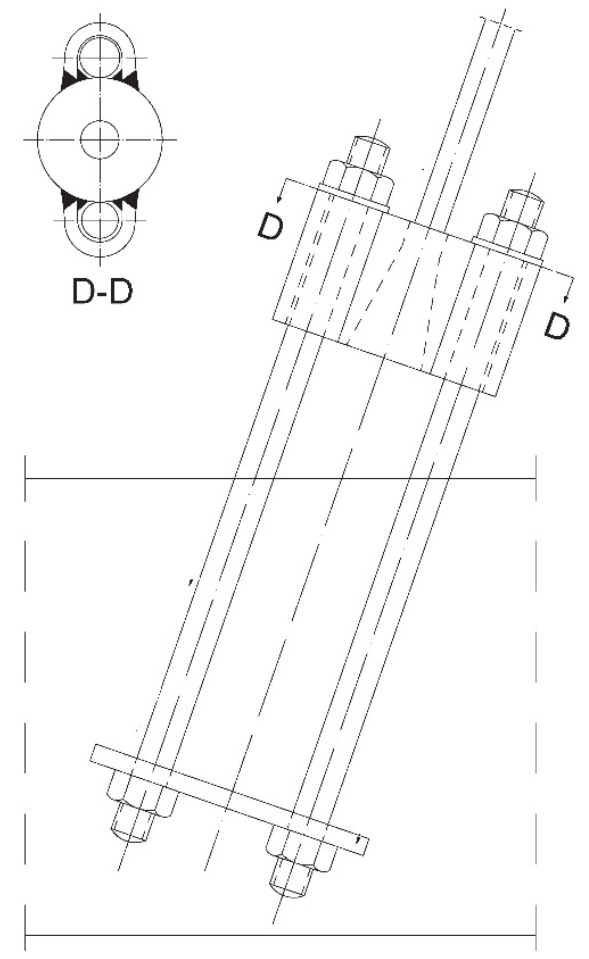

a)
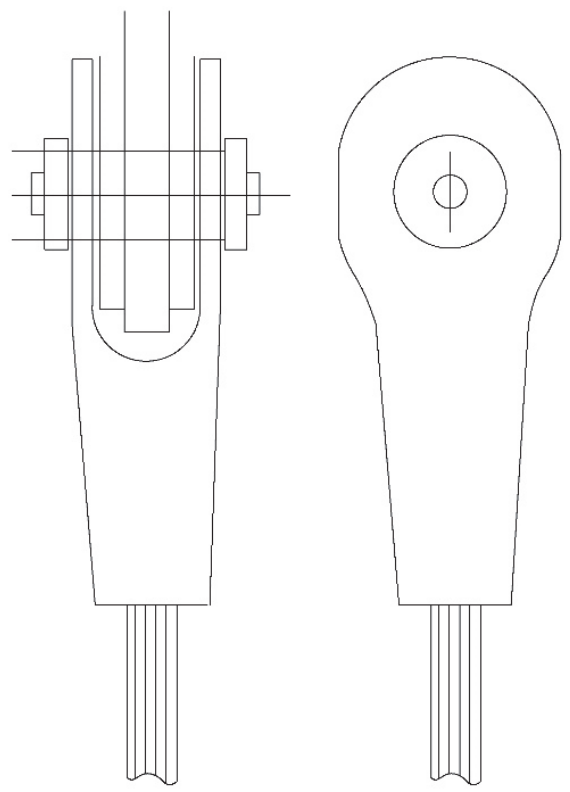

b)

Figure 10. Lower end of a hanger in a network arch (a), upper hanger (b).

\subsection{Configuration and Optimization}

The The optimization of network arches up to the span length of $200 \mathrm{~m}$ has been performed and is presented herein for the particular case of hollow tubular sections. The choice of the hollow section has been based on past studies 
(Tveit and Pipinato 2011) ensuring the best optimal use of the arches and chords, a more pleasant aesthetic, and reduced maintenance. The calculation of a ten thousands of models of net arch bridges, has enhanced the optimization model, providing recommendations for practical application. For this purpose a stepwise procedure allows the designer to have precise information on the optimal hanger geometry considering different parameters, thus the exact solution should be achieved on the base of the specific design situation. The optimization procedure has taken into consideration three network arch models considered for the optimization (Figure 11):

a) CSM, constant slope model: the constant slope of hangers solution is the most diffused construction solution, e.g. in Nielsen-Lohse bridges; built bridges of this types implies angles varying between $45^{\circ}-75^{\circ}$;

b) V-CSM, variant-constant slope model: the Tveit model (2004), is a particular subset of the CSM bridge alternative, with a constant hangers start angle of $30^{\circ}$ at the abutment and angle changes between $0.5^{\circ}$ and $3^{\circ}$;

c) CARSM, constant angle to radius slope model: the model (Brunn and Schanack 2003), with inclination of hangers between $30^{\circ}<\quad 50$. Lower values of recommended for unexpected bending concentration in the arch.

especially for $0^{\circ}<\quad<30^{\circ}$ are not

The proposed solution is based on the following parameters:

- $\quad$ number of hangers: $18(\mathrm{C} 0), 24(\mathrm{C} 1), 36(\mathrm{C} 2), 48(\mathrm{C} 3), 60(\mathrm{C} 4)$ according to previous studies as Tveit (2004) and Teich (2012); this parameter is mainly affected by the bridge span.

The parametrical analysis aiming to identify the correct number and disposition of hangers, is based on the optimization of the member capacity towards the loading conditions superimposed, minimizing the bending components on the whole principal members. In the following, the result of the optimization has been presented both for roadway and railway bridges; the main description of the analysed arches are provided herein.

a)
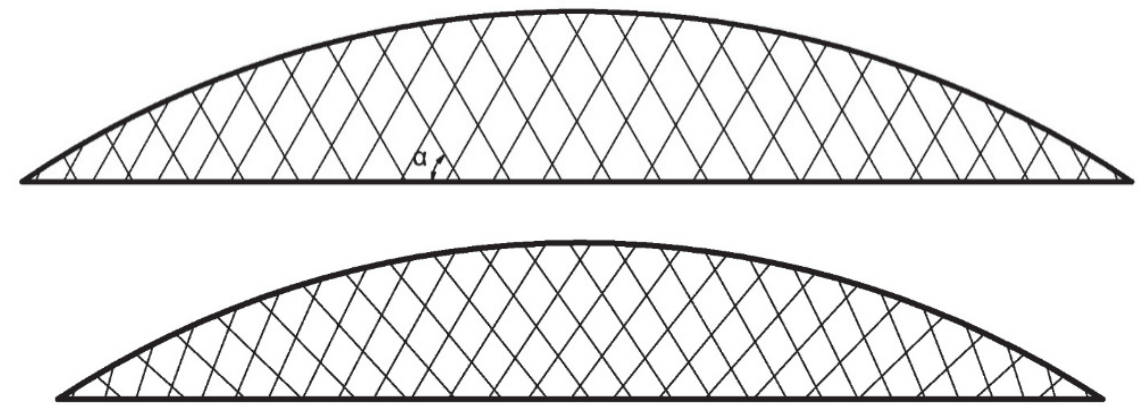

b)

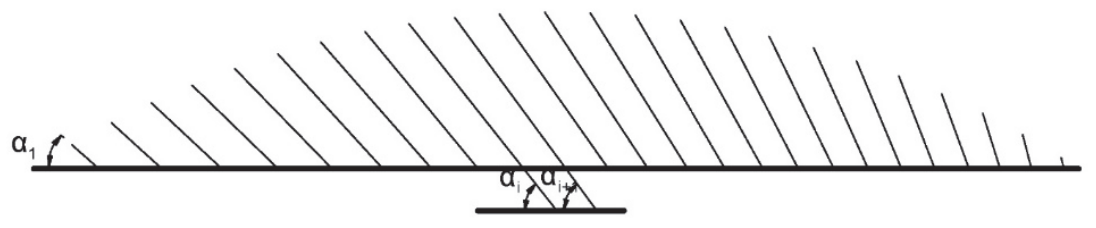

c)
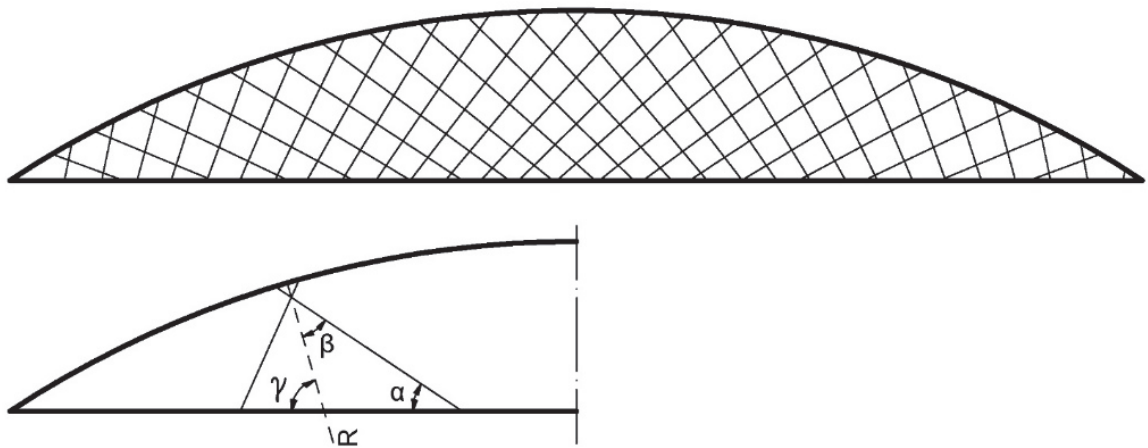

Figure 11. Network arch models considered for the optimization of network arches: CSM, constant slope model, the angle is constant (a); V-CSM, variant-constant slope model, the angle varies with a costant the (b); CARSM, constant angle to radius slope model 


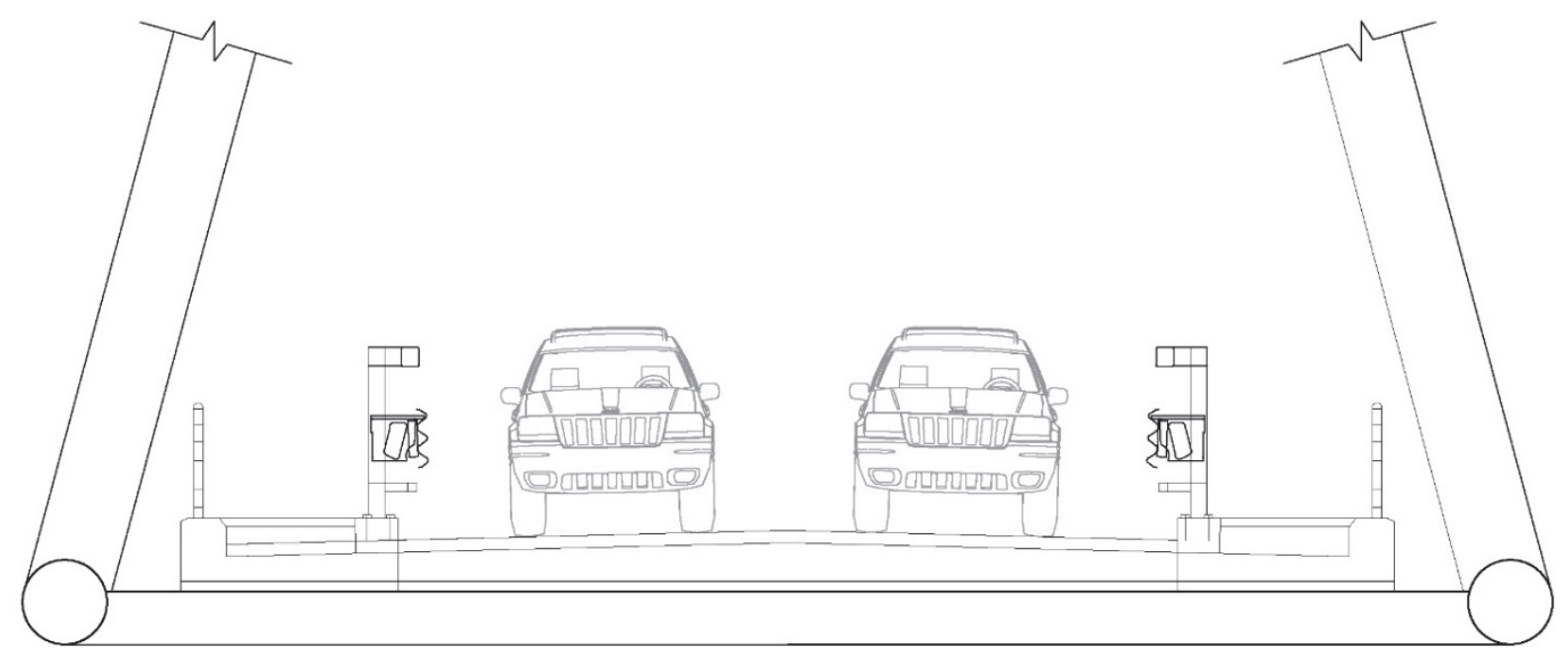

a)

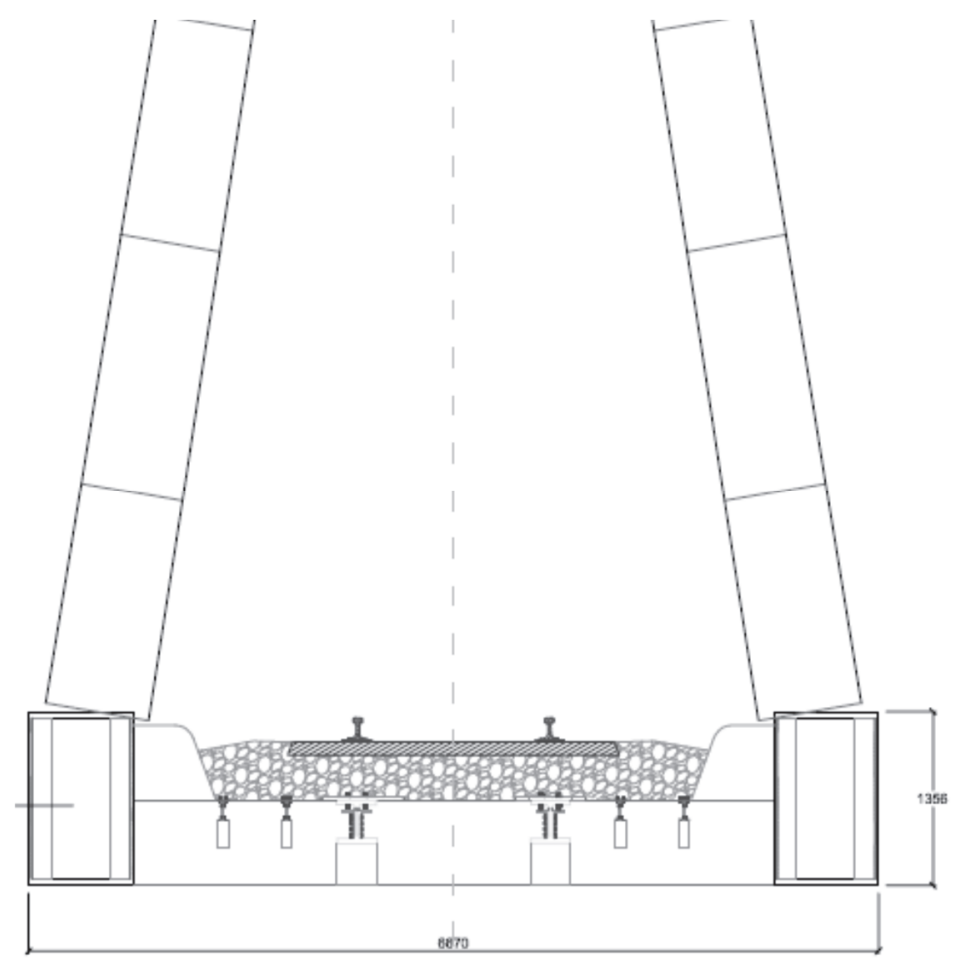

b)

Figure 12. Typical cross section of optimized bridges: two lanes road bridge (a), one way railway bridge (b).

The road bridge type has been optimized for various span, fixing the following parameters (Figure 12a):

- $\quad$ Two lane road bridge, $3.5 \mathrm{~m}$;

- Load scheme: according to EN

- Reinforced concrete constituent material: C 40/50 (reinforced concrete for the composite deck) $\mathrm{E}_{\mathrm{C}}=$ $35,22 \mathrm{GPa}, \mathrm{f}_{\mathrm{ctm}}=3,50 \mathrm{MPa}, \mathrm{f}_{\mathrm{ctk}}=2,45 \mathrm{MPa}, \mathrm{f}_{\mathrm{ck}}=40,00 \mathrm{MPa}$, Poisson ratio $\mathrm{v}=0,2$, Linear thermal expansion $\alpha=10 \times 10-6$ for ${ }^{\circ} \mathrm{C}-1$ (up to $100^{\circ} \mathrm{C}$ ), $\rho=2400 \mathrm{~kg} / \mathrm{m} 3$ )

- $\quad$ Steel reinforcement: $B 450 \mathrm{C}\left(\mathrm{EC}=210000 \mathrm{MPa} ;\right.$ fynom $=450 \mathrm{MPa} ; \mathrm{f}_{\mathrm{yk}} \geq \mathrm{f}_{\text {ynom }} ; \mathrm{f}_{\text {tnom }}=540 \mathrm{MPa} ; \mathrm{f}_{\text {tk }} \geq \mathrm{f}_{\text {tnom }}$; $\left.\mathrm{A}_{\mathrm{gt}, \mathrm{k}} \geq 7,5 \% ; 1,15 \leq\left(\mathrm{f}_{\mathrm{t}} / \mathrm{f}_{\mathrm{y}}\right) \mathrm{k}<1,35 ;\left(\mathrm{f}_{\mathrm{y}} / \mathrm{f}_{\mathrm{ynom}}\right) \mathrm{k} \leq 1,25 ; \mathrm{f}_{\mathrm{yd}}=391,3 \mathrm{MPa}\right)$ 
- $\quad$ Steel constituent material: S460NL $\left(E C=210000 \mathrm{MPa} ; \mathrm{f}_{\mathrm{yk}} \geq 460 \mathrm{MPa}\right.$ for thickness $\mathrm{t} \leq 40 \mathrm{~mm} ; \mathrm{f}_{\mathrm{yk}} \geq 430$ $\mathrm{MPa}$ for thickness $40<\mathrm{t} \leq 80 \mathrm{~mm} ; \mathrm{f}_{\mathrm{tk}} \geq 540 \mathrm{MPa}$ for thickness $\mathrm{t} \leq 40 \mathrm{~mm} ; \mathrm{f}_{\mathrm{tk}} \geq 540 \mathrm{MPa}$ for thickness 40 $<\mathrm{t} \leq 80 \mathrm{~mm} ; \mathrm{G}=\mathrm{E} /[2(1+\mathrm{v})] \mathrm{N} / \mathrm{mm}^{2}$; Poisson ratio $\mathrm{v}=0,3$; Linear thermal expansion $\alpha=12 \times 10-6$ for ${ }^{\circ} \mathrm{C}-1$ (up to $100{ }^{\circ} \mathrm{C}$ ); $\rho=7850 \mathrm{~kg} / \mathrm{m} 3$ );

- $\quad$ Hangers: steel cables, $\mathrm{E}=160000 \mathrm{MPa} ; \mathrm{f}_{\mathrm{uk}}=1770 \mathrm{MPa}$;

- Deck type: composite deck, with commercial or I-built carbon steel transverse;

- Presence of foot paths: yes on both directions, inside arches.

The railway bridge type has been optimized for various span, fixing the following parameters (Figure 12b):

- $\quad$ One way, one track railway bridge;

- Load scheme: according to EN

- Reinforced concrete constituent material: C 40/50 (reinforced concrete for the composite deck) $\mathrm{E}_{\mathrm{C}}=$ $35,22 \mathrm{GPa}, \mathrm{f}_{\mathrm{ctm}}=3,50 \mathrm{MPa}, \mathrm{f}_{\mathrm{ctk}}=2,45 \mathrm{MPa}, \mathrm{f}_{\mathrm{ck}}=40,00 \mathrm{MPa}$, Poisson ratio $\mathrm{v}=0,2$, Linear thermal expansion $\alpha=10 \times 10-6$ for ${ }^{\circ} \mathrm{C}-1$ (up to $100{ }^{\circ} \mathrm{C}$ ), $\rho=2400 \mathrm{~kg} / \mathrm{m} 3$ )

- $\quad$ Steel reinforcement: $B 450 \mathrm{C}\left(\mathrm{EC}=210000 \mathrm{MPa} ;\right.$ fynom $=450 \mathrm{MPa} ; \mathrm{f}_{\mathrm{yk}} \geq \mathrm{f}_{\text {ynom }} ; \mathrm{f}_{\text {tnom }}=540 \mathrm{MPa} ; \mathrm{f}_{\text {tk }} \geq \mathrm{f}_{\text {tnom }}$; $\left.\mathrm{A}_{\mathrm{gt}, \mathrm{k}} \geq 7,5 \% ; 1,15 \leq\left(\mathrm{f}_{\mathrm{t}} / \mathrm{f}_{\mathrm{y}}\right) \mathrm{k}<1,35 ;\left(\mathrm{f}_{\mathrm{y}} / \mathrm{f}_{\mathrm{ynom}}\right) \mathrm{k} \leq 1,25 ; \mathrm{f}_{\mathrm{yd}}=391,3 \mathrm{MPa}\right) ;$

- $\quad$ Steel constituent material: S460NL (EC $=210000 \mathrm{MPa} ; \mathrm{f}_{\mathrm{yk}} \geq 460 \mathrm{MPa}$ for thickness $\mathrm{t} \leq 40 \mathrm{~mm} ; \mathrm{f}_{\mathrm{yk}} \geq 430$ $\mathrm{MPa}$ for thickness $40<\mathrm{t} \leq 80 \mathrm{~mm} ; \mathrm{f}_{\mathrm{tk}} \geq 540 \mathrm{MPa}$ for thickness $\mathrm{t} \leq 40 \mathrm{~mm} ; \mathrm{f}_{\mathrm{tk}} \geq 540 \mathrm{MPa}$ for thickness 40 $<\mathrm{t} \leq 80 \mathrm{~mm} ; \mathrm{G}=\mathrm{E} /[2(1+\mathrm{v})] \mathrm{N} / \mathrm{mm}^{2}$; Poisson ratio $\mathrm{v}=0,3$; Linear thermal expansion $\alpha=12 \times 10-6$ for ${ }^{\circ} \mathrm{C}-1$ (up to $100{ }^{\circ} \mathrm{C}$ ); $\rho=7850 \mathrm{~kg} / \mathrm{m} 3$ );

- $\quad$ Hangers: steel cables, $\mathrm{E}=160000 \mathrm{MPa} ; \mathrm{f}_{\mathrm{uk}}=1770 \mathrm{MPa}$;

- Deck type: composite deck, with commercial or I-built carbon steel transverse and longitudinals;

- Presence of foot paths: yes on both directions, out of arches.

\section{Optimization of the Bridge Network Arches}

The following step have been performed for every type of models presented before (CSM, V-CSM, CARSM), with reference to Figure 13 arch portion:

- $\quad$ minimization of the compression $\mathrm{N}$ in the arch, analysing both the lower part of the arch between the portal transverse and the road (A), and the centre of the arch between the two portal transverse (B);

- $\quad$ minimization of the bending moments $\mathrm{M}$ in the arch, analysing both the lower part of the arch between the portal transverse and the road (A), and the centre of the arch between the two portal transverse (B);

- $\quad$ minimization of the stress level in the arches.

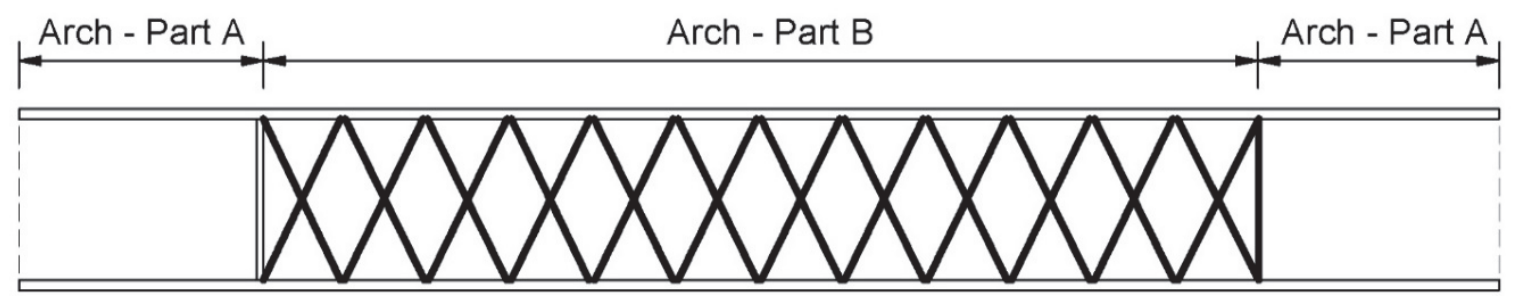

Figure 13. Identification of the arch portions: A, up to the portal transverse; B, central part.

According to the previous steps performed, a synthesis of the results is reported in the figures below:

- $\quad$ in Figure 14 an example of the railway arch compression optimization is reported for the CSM alternative, $120 \mathrm{~m}$ span, varying the angle of hangers; the other alternatives are quite similar to these results; a further comparison of the whole alternatives (CSM, V-CSM, CARSM), is reported in figure 15; analogous figures (16-17) are reported for the roadway case;

in Figure 18 an example of the railway arch bending optimization is reported for the CSM alternative, $120 \mathrm{~m}$ span, varying the angle of hangers; the other alternatives are quite similar to these results; the figure 19 illustrates the roadway case; 
- $\quad$ in Figure 20 an example of the arch stress optimization is reported for a $120 \mathrm{~m}$ span railway bridge, varying the angle of hangers, and considering a hollow arch and wind-bracings cross section ( $\operatorname{arch}: \mathrm{B}=740 \mathrm{~mm}, \mathrm{~h}=740$ $\mathrm{mm}, \mathrm{t}=100 \mathrm{~mm}$; wind-bracings: $\mathrm{B}=560 \mathrm{~mm}, \mathrm{~h}=560 \mathrm{~mm}, \mathrm{t}=80 \mathrm{~mm}$ ) including the comparison of the whole alternatives (CSM, V-CSM, CARSM); the roadway case is reported in figure 21 .

The further implementation of the different alternatives, has been implemented with Midas Civil (2016), supported by a computer routine in $\mathrm{C}++$ providing the different parameter variation in the FEM input/output. According to the analysis performed, resume tables has been prepared for the hanger net optimal geometry: Tables 2-3 represent the optimal geometry alternative starting from the choice of the hanger number and the bridge span for the road and the railway alternative. The determination of the optimal inclination parameters for the selected alternative should be made according to Figure 22-23, while for CSM alternative, indications are given in Table 4.

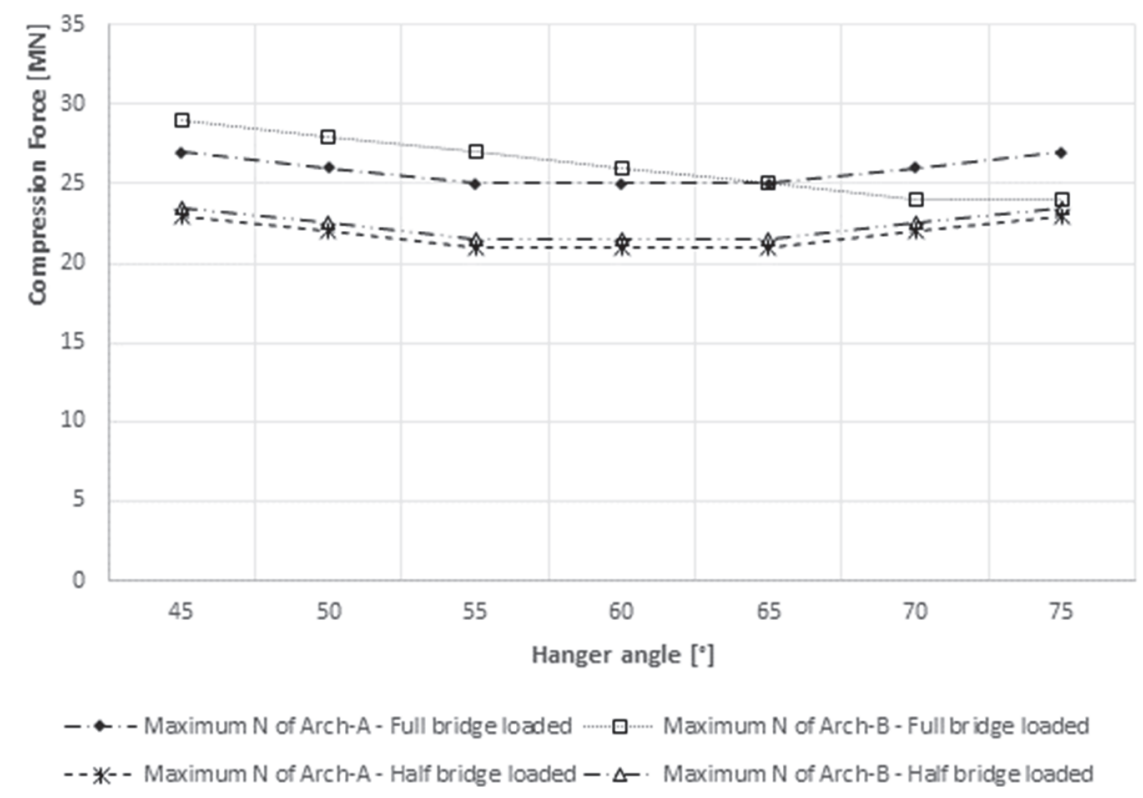

Figure 14. Maximum N-compression force in the arch as a function of the hanger angle inclination (CSM configuration), railway bridge alternative

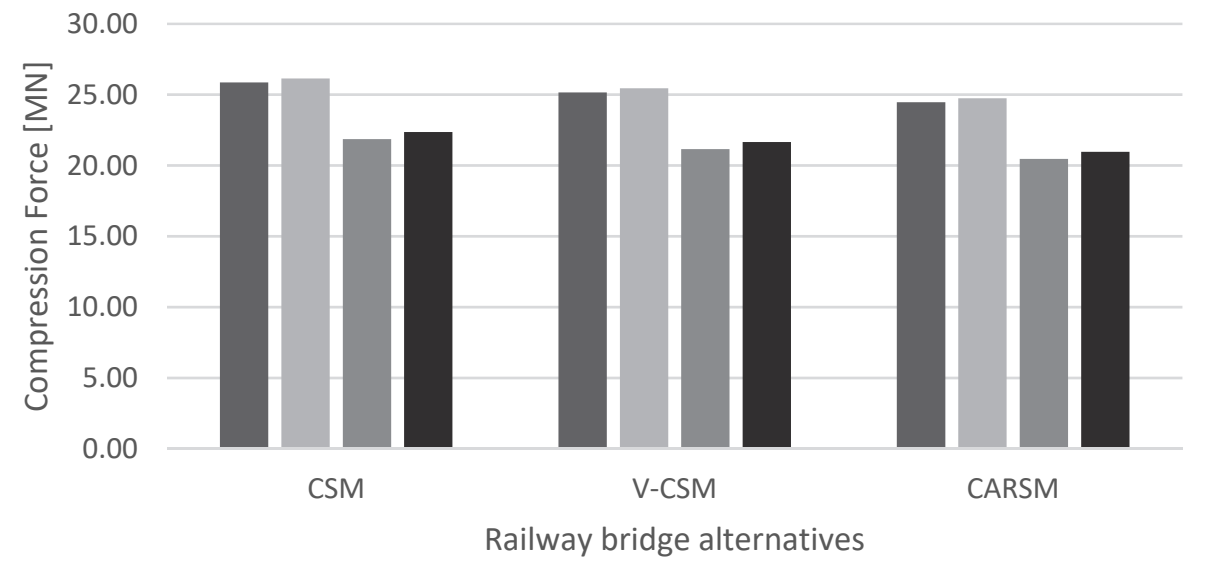

arch-A - Full bridge loaded $\square$ Arch-B - Full bridge loaded

Arch-A - Half bridge loaded $\mathbf{a}$ Arch-B - Half bridge loaded

Figure 15. Mean values of the compression force in the arch (all configuration), railway bridge alternative. 


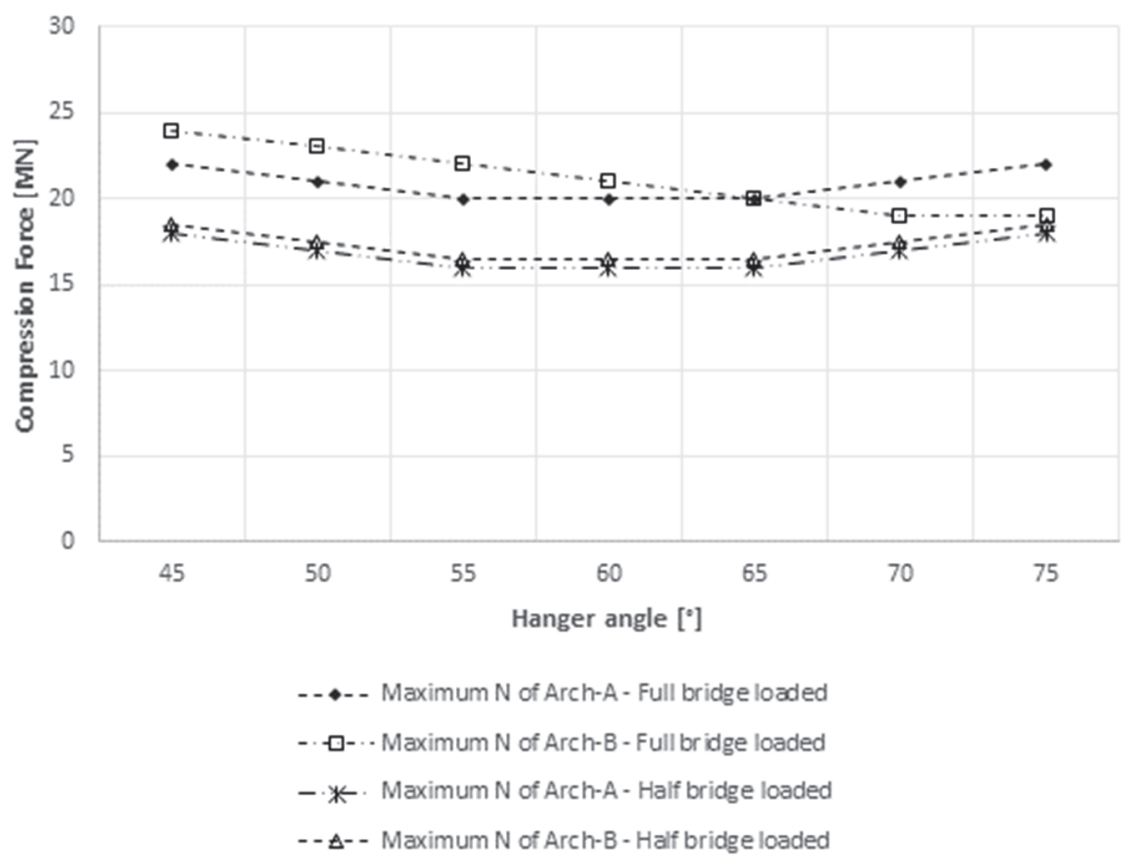

Figure 16. Maximum N-compression force in the arch as a function of the hanger angle inclination (CSM configuration), roadway bridge alternative

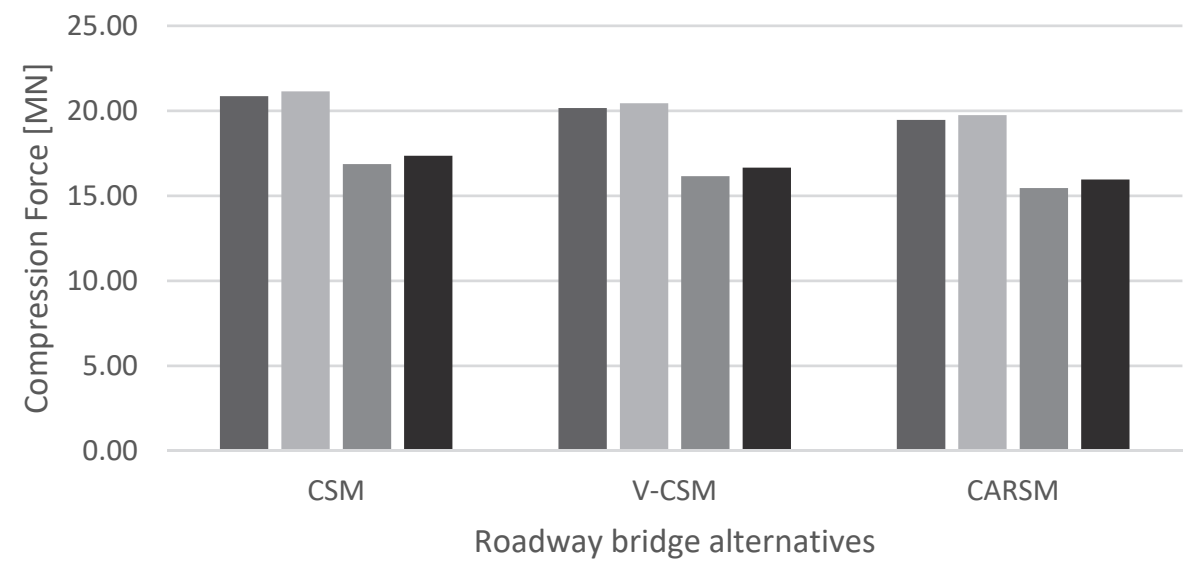

- Arch-A - Full bridge loaded $\square$ Arch-B - Full bridge loaded

- Arch-A - Half bridge loaded Arch-B - Half bridge loaded

Figure 17. Mean values of the compression force in the arch (all configuration), roadway bridge alternative. 


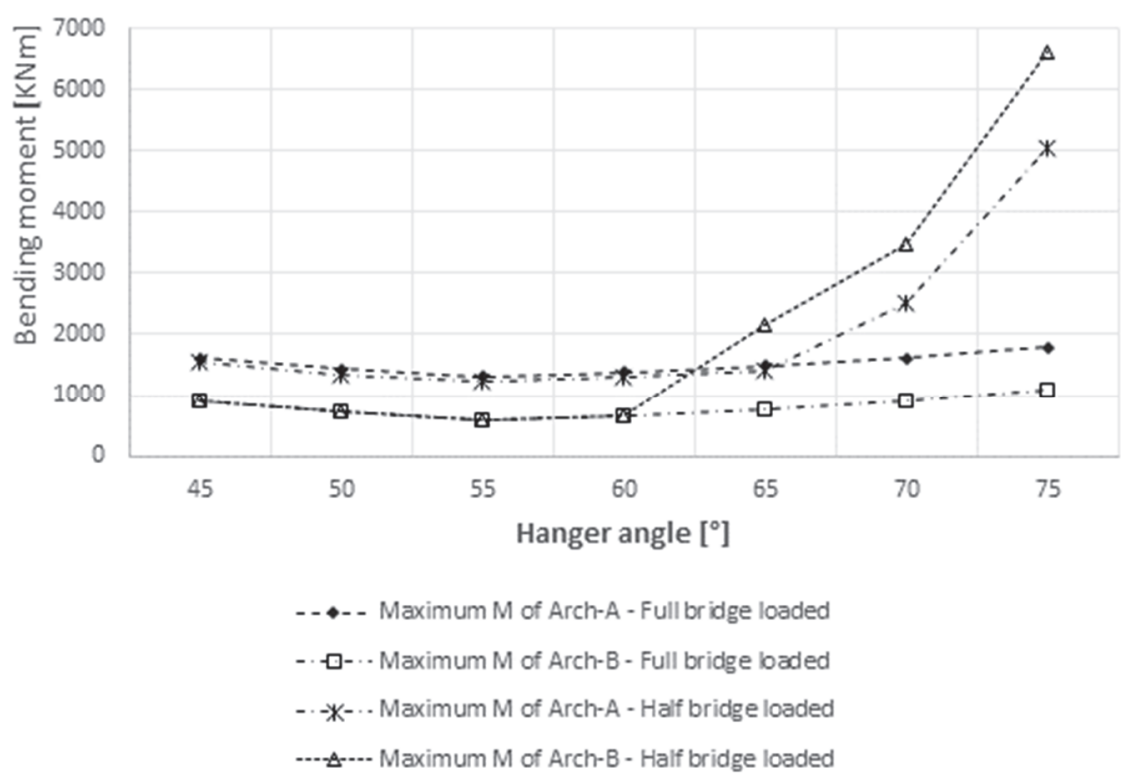

Figure 18. Maximum bending moment in the arch as a function of the hanger angle inclination (CSM configuration), railway bridge alternative

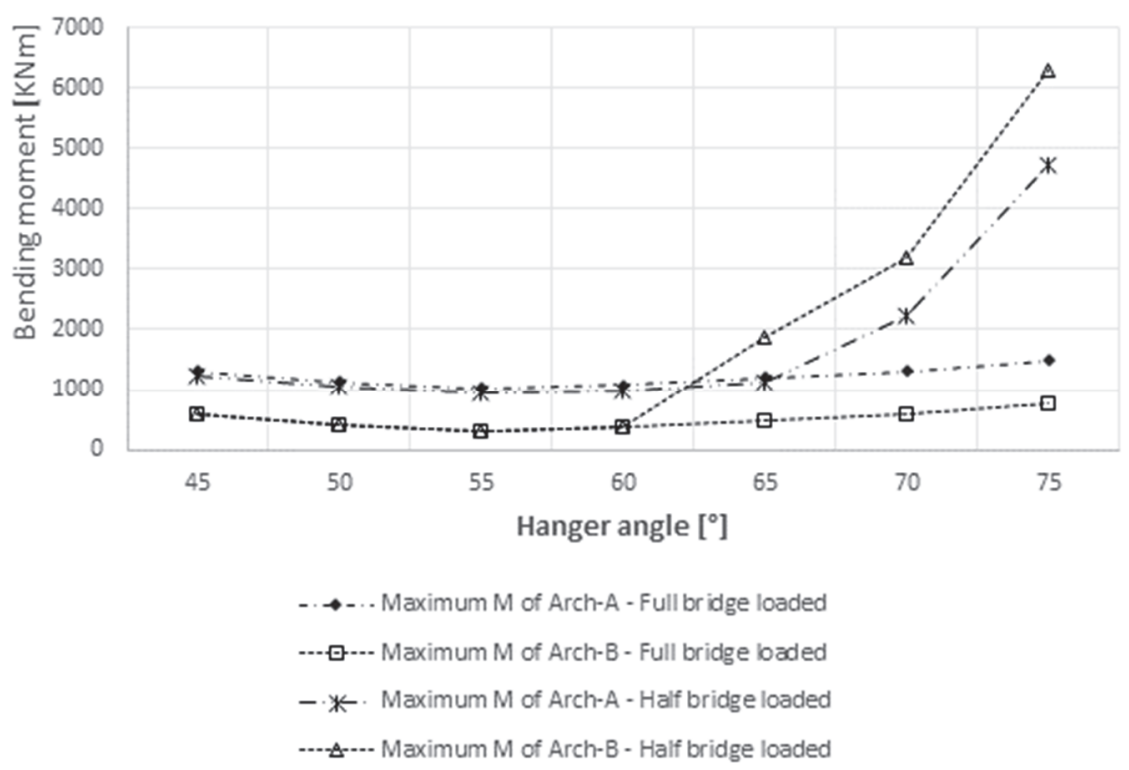

Figure 19. Maximum bending moment in the arch as a function of the hanger angle inclination (CSM configuration), roadway bridge alternative 


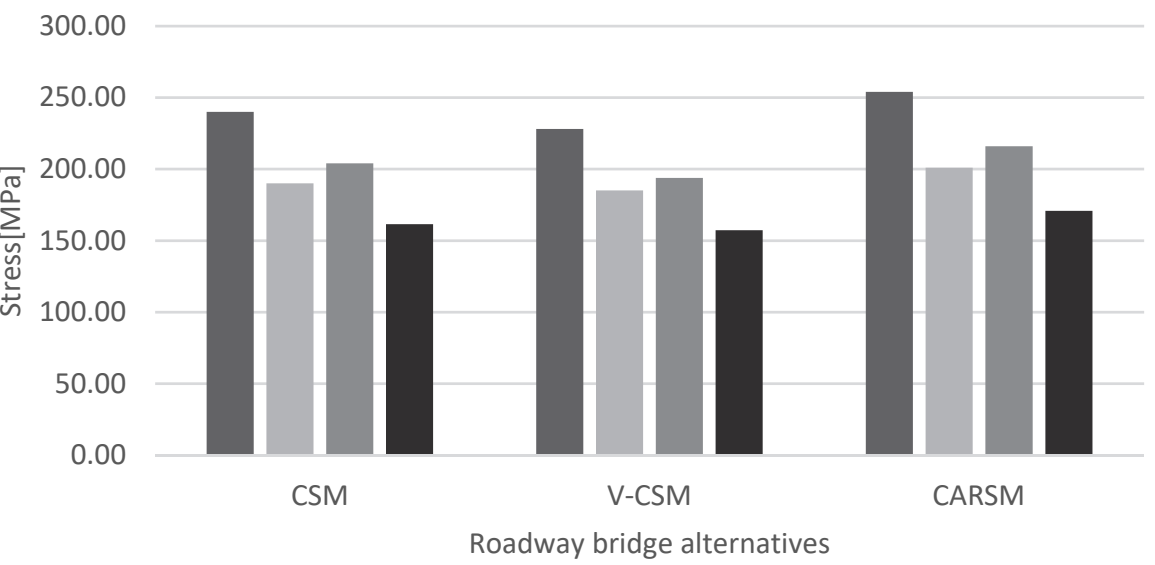

arch-A - Full bridge loaded $\square$ Arch-B - Full bridge loaded

- Arch-A - Half bridge loaded arch-B - Half bridge loaded

Figure 20. Mean values of the stress the arch (all configuration), railway bridge alternative.

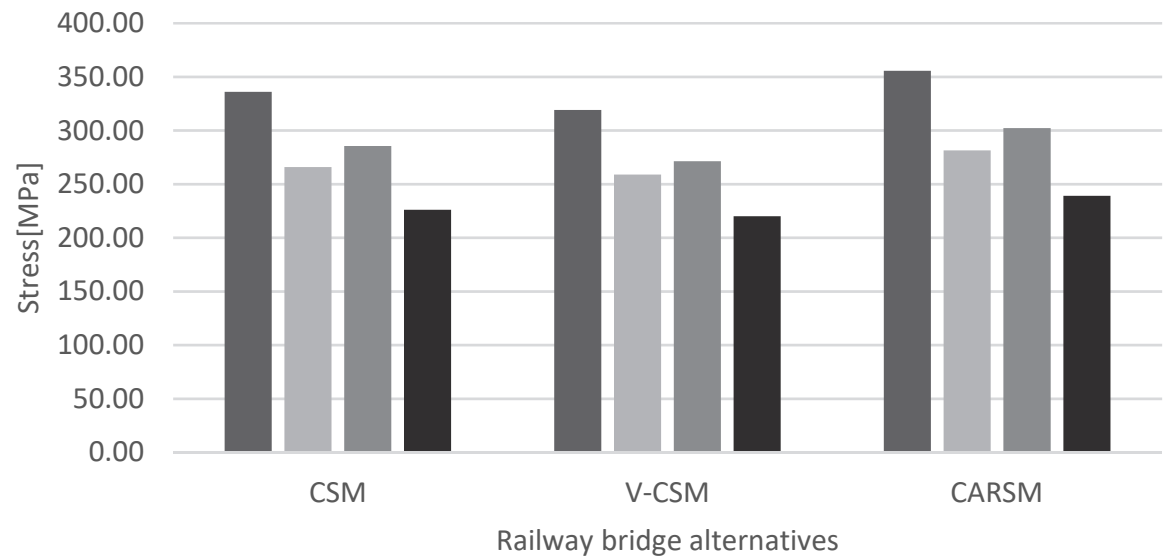

- Arch-A - Full bridge loaded $\square$ Arch-B - Full bridge loaded

Arch-A - Half bridge loaded A Arch-B - Half bridge loaded

Figure 21. Mean values of the stress the arch (all configuration), roadway bridge alternative

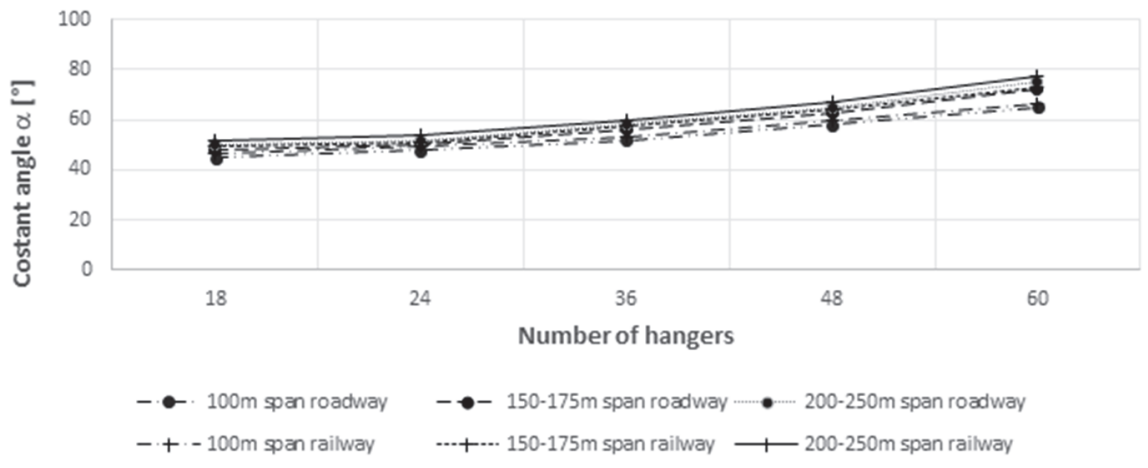

Figure 22. Optimal inclination parameters for the CSM alternative 


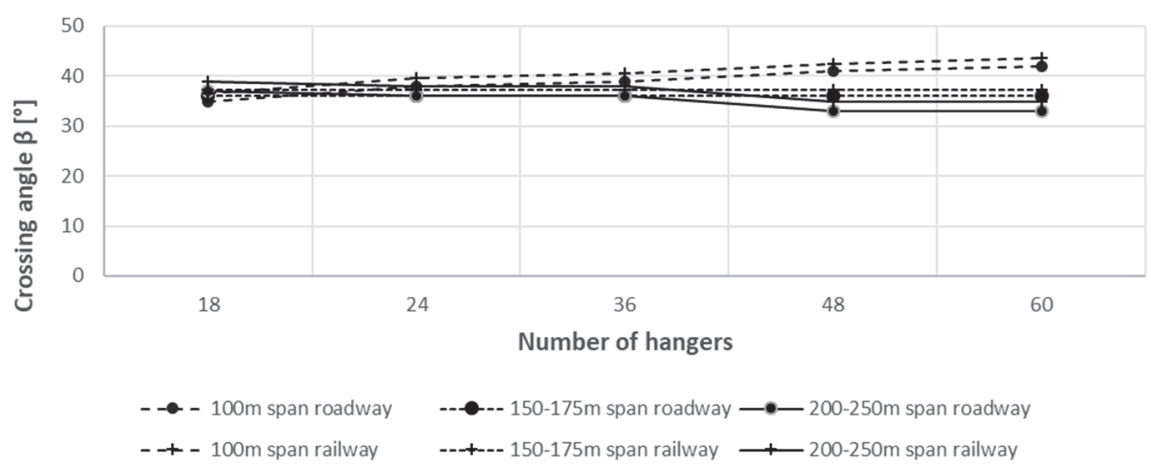

Figure 23. Optimal inclination parameters for the CARSM alternative

Table 2. Optimization of the hanger geometry of a network arch, roadway solution.

\begin{tabular}{cccccc}
\hline Span lenght $[\mathrm{m}]$ vs. Hanger number & 18 & 24 & 36 & 48 & 60 \\
\hline 60 & V-CSM & V-CSM & V-CSM & V-CSM & V-CSM \\
70 & V-CSM & V-CSM & V-CSM & V-CSM & V-CSM \\
80 & V-CSM & V-CSM & V-CSM & V-CSM & V-CSM \\
90 & V-CSM & V-CSM & V-CSM & V-CSM & V-CSM \\
100 & V-CSM & V-CSM & CARSM & CARSM & CARSM \\
110 & V-CSM & CARSM & CARSM & CARSM & CARSM \\
120 & CARSM & CARSM & CARSM & CARSM & CARSM \\
130 & CARSM & CARSM & CARSM & CARSM & CARSM \\
140 & CARSM & CARSM & CARSM & CARSM & CARSM \\
150 & CARSM & CARSM & CARSM & CARSM & CARSM \\
160 & CARSM & CARSM & CARSM & CARSM & CARSM \\
170 & CARSM & CARSM & CARSM & CARSM & V-CSM \\
180 & CARSM & CARSM & CARSM & V-CSM & V-CSM \\
190 & CARSM & CARSM & CARSM & V-CSM & V-CSM \\
200 & CARSM & CARSM & V-CSM & V-CSM & CARSM/V-CSM \\
\hline
\end{tabular}

Table 3. Optimization of the hanger geometry of a network arch, railway solution.

\begin{tabular}{cccccc}
\hline Span lenght [m] vs. Hanger number & 18 & 24 & 36 & 48 & 60 \\
\hline 60 & V-CSM & V-CSM & V-CSM & CARSM & CARSM \\
70 & V-CSM & V-CSM & CARSM & CARSM & CARSM \\
& & CARS & & & \\
80 & V-CSM & M & CARSM & CARSM & CARSM \\
90 & CARS & CARS & & & \\
& M & M & CARSM & CARSM & CARSM \\
100 & CARS & CARS & & & \\
& CARS & CARS & & CARSM & CARSM \\
110 & CARSM & M & CARSM & CARSM & CARSM \\
& CARS & & & \\
\hline
\end{tabular}




\begin{tabular}{|c|c|c|c|c|c|}
\hline & CARS & CARS & & & \\
\hline \multirow[t]{2}{*}{130} & $\mathrm{M}$ & M & CARSM & CARSM & CARSM \\
\hline & CARS & CARS & & & \\
\hline \multirow[t]{2}{*}{140} & $\mathrm{M}$ & M & CARSM & CARSM & CARSM \\
\hline & CARS & CARS & & & \\
\hline \multirow[t]{2}{*}{150} & $\mathrm{M}$ & M & CARSM & CARSM & CARSM \\
\hline & CARS & CARS & & & \\
\hline \multirow[t]{2}{*}{160} & M & $\mathrm{M}$ & CARSM & CARSM & CARSM \\
\hline & CARS & CARS & & & CARSM/V-CS \\
\hline \multirow[t]{2}{*}{170} & $\mathrm{M}$ & $\mathrm{M}$ & CARSM & CARSM & $\mathrm{M}$ \\
\hline & CARS & CARS & & CARSM/V-CS & CARSM/V-CS \\
\hline \multirow[t]{2}{*}{180} & M & $\mathrm{M}$ & CARSM & M & $\mathrm{M}$ \\
\hline & CARS & CARS & & CARSM/V-CS & CARSM/V-CS \\
\hline \multirow[t]{2}{*}{190} & M & M & CARSM & M & $\mathrm{M}$ \\
\hline & CARS & CARS & CARSM/V-CS & CARSM/V-CS & CARSM/V-CS \\
\hline 200 & M & M & M & M & $\mathrm{M}$ \\
\hline
\end{tabular}

Table 4. Optimal inclination parameters for the V-CSM alternative.

\begin{tabular}{cccccccc}
\hline & Number of hangers & 18 & 24 & 36 & 48 & 60 \\
\hline Roadway & span length $<100 \mathrm{~m}$ & 1 & $37^{\circ}$ & $35^{\circ}$ & $30^{\circ}$ & $20^{\circ}$ & $18^{\circ}$ \\
& span length $<100 \mathrm{~m}$ & & $3^{\circ}$ & $3^{\circ}$ & $3^{\circ}$ & $3^{\circ}$ & $2,50^{\circ}$ \\
& $100 \mathrm{~m}<$ span length & 1 & $37^{\circ}$ & $35^{\circ}$ & $30^{\circ}$ & $20^{\circ}$ & $18^{\circ}$ \\
& $100 \mathrm{~m}<$ span length & & $33^{\circ}$ & $3^{\circ}$ & $3^{\circ}$ & $3^{\circ}$ & $2,50^{\circ}$ \\
\multirow{5}{*}{ Railway } & span length $<100 \mathrm{~m}$ & 1 & $37^{\circ}$ & $35^{\circ}$ & $30^{\circ}$ & $20^{\circ}$ & $18^{\circ}$ \\
& span length $<100 \mathrm{~m}$ & & $3^{\circ}$ & $3^{\circ}$ & $2,75^{\circ}$ & $2,75^{\circ}$ & $2,50^{\circ}$ \\
& $100 \mathrm{~m}<$ span length & 1 & $37^{\circ}$ & $35^{\circ}$ & $30^{\circ}$ & $20^{\circ}$ & $18^{\circ}$ \\
& $100 \mathrm{~m}<$ span length & & $3^{\circ}$ & $3^{\circ}$ & $2,75^{\circ}$ & $2,75^{\circ}$ & $2,50^{\circ}$ \\
\hline
\end{tabular}

\section{Conclusion}

In this study, network arch bridges optimization with hollow structural member has been presented. The network arch main positive issues have been explained and presented also with reference with real case bridges. The idea comes from the past, as first drawing of similar solution appeared in 1482, in a manuscript of Leonardo Da Vinci, designing in the "Codex Atlanticus" a truss arch with inclined hangers, probably wooden made. In 1796, American engineer Robert Fulton published a design of a bridge with a type of truss beam that he called "bowstring." A wide amount of studies have been published also in the recent years, however, the diffusion of this type of bridge solution has not reached the clear and hopeful evidence that should really deserve.

The shape of the case study arches considered in this study is chosen after a parametric analysis, finalized to minimize:

- the steel amount needed to carry the live and

- the dead load of the solution investigated.

In the second part, the paper illustrates an optimization study performed according to three main models:

- the CSM, constant slope model,

- the V-CSM, variant-constant slope model,

- and the CARSM, constant angle to radius slope solution.

For each alternative a roadway and a railway application has been dimensioned for different span length, 
illustrating the possible configuration of the cables in each arch. According to the optimization performed, the designer could focus directly to the alternative that is considered more adherent to the specific design, avoiding for successive optimizations of the cables disposition, and going directly to a FEM model and to structural design and calculation of details. The further implementation of the different alternatives, has been implemented with Midas Civil (2016), supported by a computer routine in $\mathrm{C}++$ providing the different parameter variation in the FEM input/output. According to the analysis performed, resume tables has been prepared for the hanger net optimal geometry: Tables 2-3 represent the optimal geometry alternative starting from the choice of the hanger number and the bridge span for the road and the railway alternative. The determination of the optimal inclination parameters for the selected alternative should be made according to Figure 22-23, while for CSM alternative, indications are given in Table 4.

The study will be in the near future enlarged, including:

- the alternative with four lane, which is more interesting especially for increasing span length and highway solution;

- the analysis of theoretical span-limit of CFST network arches, which appear to be the frontier of medium span bridges, for their easy construction and robust structural solution;

- the convenience of multi-span net-arch bridges compared to traditional long-span bridge types (e.g., suspension or cable stay).

\section{References}

Brunn, B., \& Schanack, F. (2003). Berechnung einer zweigleisigen Eisenbahn-Netzwerkbogenbrücke unter Einsatz des europäischen Normenkonzeptes Diplomarbeit, Technische Universität Dresden.

Brunn, B., Schanack, F., \& Steimann, U. (2004). Network Arches for Railway Bridges. Arch Bridges IV, Barcelona, Nov. 2004. Advances in Assessment, Structural Design and Construction. P. Roca and C. Molins (Eds.). pp. 671-680. ISBN: 84-95999-63-3.

Dimopoulos, C. A., Gantes, C. J. (2008). Design of circular steel arches with hollow circular cross-sections according to EC3. Journal of Contructional Steel research (2008). https://doi.org/10.1016/j.jcsr.2007.09.009

Geißler, K., Steimann, U., \& Graße, W. (2008). Netzwerkbogenbrücken - Entwurf, Bemessung, Ausführung Stahlbau, 77(2008), Heft 3, S. $158-171$.

Griggs, Jr., F. E., (2002). Squire Whipple: father of iron bridges. J. Bridge Eng, 7(3), 146-155.

Müller-Donges, R. (2003). Straßenbrücken in Stahlverbund-2.2. Mainbrücke in Marktheidenfeld Internationales Brückenbausymposium, Darmstadt, 2003.

Nielsen, O. F. (1929). Foranderlige Systemer med anvendelse på buer med skraatstillede Hængestenger. ("Discontinuous systems used on arches with inclined hangers", in Danish.) 121 pages. Gad Copenhagen. Ph.D. thesis.

Pipinato A. (2016). Structural analysis and design of multi-span network arch bridge. Journal of ICE - Institution of Civil Engineers - Bridge Engineering 169 March 2016 Issue BE1, Pages 54-66 http://dx.doi.org/10.1680/jbren.14.00013, Thomas Telford Ltd, London.

Schanack, F., \& Brunn, B. (2009). Analysis of the structural performance of network arch bridges. The Indian Concrete Journal, 83(1), ACC limited, 2009. pp. 7-13.

Schanack, F., \& Ramos, O. (2016). Arch bridges. Innovative Bridge Design Handbook, Edited by Alessio Pipinato, Elsevier Science, pp. 335-357.

Schömig, W. (2000). Mainbrücke an der NATO-Rampe zwischen den Gemarkungen Sulzbach und Niedernberg, Stahlbau 69 (2000), Heft 5, S. 387-390.

Stein, P., \& Wild, H. (1965). Das Bogentragwerk der Fehmarnsundbrücke. Stahlbau 34, Heft 6, S. 171-86.

Teich. S. (2012). Beitrag zur Optimierung von Netzwerkbogenbrüken (Contrbution to Optimizing Network Arch Bridges). PhD. Thesis TU Dresden. ISSN 1613-6934.

Tveit, P. (1966). Design of Network Arches. Struct. Eng, 44(7). London, England, pp. 247-259.

Tveit, P. (2002). Optimal design of network arches. Contribution to the IABSE Symposium in Melbourne 2002. 13 pages. ISBN 3-85748-107-2

Tveit, P. (2008). Concrete in the optimal network arch. Proceedings of the International fib Symposium 2008, 
Amsterdam, 19-21 May 2008. Editors: Walraven, J. and Stoelhorst, D. p. 164.

Tveit, P. (2010). Optimal network arches for road and rail bridges. ARCH'10. 6th International Conference on Arch Bridges. Fuzhou, Fujian, China. October 11-13, 2010. Editors Baochun Chen, Jiangang Wei. pp. 271-277.

Tveit, P., \& Pipinato, A. (2011). II progretto di Ponti di tipo network-arch. (The network-arch bridge) In Italian. Costruzione Matalliche. Mar/Apr 2011, Pp. 47-56. ISSN nº 0010-9673.

Zoltowski, K. (2005). Bogenbrücke über den Fluß Dziwna in Wolin - Entwurf und Realisierung. Stahlbau 74 (2005), Heft 9, S. 686-690.

\section{Copyrights}

Copyright for this article is retained by the author(s), with first publication rights granted to the journal.

This is an open-access article distributed under the terms and conditions of the Creative Commons Attribution license (http://creativecommons.org/licenses/by/4.0/). 